\title{
The Influence of Study Performance and Family Background to Entrepreneurship Motivation
}

\author{
R. Mardiana, M. S. Barliana, Bachtiar Hasan \\ Vocational Technology Education Study Programs \\ School of Postgraduate Studies, Indonesia University of \\ Education \\ Bandung, West Java, Indonesia \\ riskhamardiana@yahoo.com
}

\begin{abstract}
The purpose of research is to know how big the influence of study performance and family background to entrepreneurship motivation for student of Architecture Technic and Architecture Education in DPTA UPI. Number of research population is 66 students, and using sample from 2011 students which number is 61. The method that used in this research is quantitative approach with descriptive correlation. The analysis of pre-requisite test consists of normality test and simple regression. Data collection instrument in this research using questionnaire to get family background and entrepreneurship motivation, which created base on some points that already settled before. Family background questionnaire is used to measure $\mathrm{X} 2$ variable, while entrepreneurship motivation questionnaire is used to measure $Y$ variable. The result of data processing found that: The influence of study performance to entrepeneurship motivation for both Achitecture Technic and Architecture Education students is low. The influence of family background to entrepeneurship motivation for the students of Achitecture Technic is low, while for the students of Architecture Education is very low. The influence of study performance and family background for student of Architecture Technic is low, while for students of Architechture Education is very low.
\end{abstract}

Keywords-Study Performance, Family Background, Entrepeneurship Motivation

\section{INTRODUCTION}

One of the recent main problems that is faced by this country is unemployment. The unemployment rate is keep increasing each year. Most of the unemployed people in Indonesia are actually university graduate. The high unemployment rate from university graduate is caused by the difficulties that are faced by them when they are trying to get a job. Besides, most of the university graduates are tend to be job seeker rather than job creator. The education system that is applied in numerous higher education institutions is mainly focused on preparing the students to graduate quickly and get a job, instead of preparing them to create job.

Regarding this problem, it is expected that the students not to rely only on the jobs in governmental sector or certain positions, but they are also expected to take advantages from their knowledge and to use the existing chances to work for themselves. Business has a noticeable role in decreasing the unemployment rate in university graduate. The students are not only expected to look for a job, but also to create jobs.

This condition triggers a question whether or not learning achievement and family background could be a motivation to have a business among the students. Therefore, this study entitled "The Impact of Learning Achievement and Family Background to Business Motivation among the Students of the Department of Architectural Engineering Education, Indonesia University of Education, Bandung".

\section{MEthodology}

The quantitative research approach with descriptivecorrelative method is applied in this research. Quantitative research approach is a type of research approach that copes with numerals, the data are in the form of number, and analyzed with statistical methods to answer the specified research questions or to prove the hypothesis. This research uses the methods of correlation as it aims to reveal the effect between two or more variables.

Correlative research is a form of research that is conducted to reveal the state of relationship between two or more variables without applying any changes, addition, or manipulation to the existing data [1].

This research is going to discover the influence between several variables, i.e. grades or learning achievement in business education $\left(\mathrm{X}_{1}\right)$ and family background $\left(\mathrm{X}_{2}\right)$ with the motivation to run a business $(\mathrm{Y})$. The correlation and regression analyses will be used in this correlative study.

\section{RESULTS}

\section{A. Learning Achievement}

In the architectural engineering study program, 4 students got a $\mathrm{C}$ mark ranging from 70-77, 21 students got a $\mathrm{B}$ mark ranging from 70-84, and 6 students got an A ranging from 85100. While in the architectural engineering education study 
program, four students got a C mark, 19 students got a B mark, and 7 students got an A.

\section{B. The effect of family background to the motivation to run a business}

Student's background is a part of family education that is basically a part of informal education that is running as a longlife education to acquire values, behavior, motivation, skills, and knowledge from daily life experience. The influence of society is also considered as a part of it, as it shows the relation between family and the surrounding, and between family and job. The result of architectural engineering study program shows that family background has a significant role to student's motivation to run a business. IT is in line with the results of simple regression one-variable analysis, whereas the value of $t_{\text {count }}$ is 0.361 which means that family background has positive relations to the motivation to run a business. Rate of $\mathrm{X}_{2}$ and $\mathrm{Y}$ is in the coefficient interval between 0.20 until 0.399 [2]. Therefore, it is on the low category the family background creates $13.03 \%$ of the overall motivation to run a business while the other $86.97 \%$ is determined by the other factors.

\section{The effect of learning achievement and family background to the motivation to run a business}

Basically, education and family are two extrinsic factors that triggers motivation. However, the two aspects seem not to prove strong relationship with the motivation to run a business. This is proven in the calculation in two study programs, i.e. architectural engineering and architectural engineering education. In the architectural engineering study program, the learning motivation and family background are making positive and significant influence to the motivation to run a business. It is in line with the results of simple regression analysis whereas the score of $t_{\text {count }}$ is positive 0.362 . It means that the learning motivation and family background has strong relationship to the motivation to run a business. As the coefficient score is positive 0.362 , it can be inferred that learning motivation $\left(\mathrm{X}_{1}\right)$ and family background $\left(\mathrm{X}_{2}\right)$ influences the motivation to run a business $(\mathrm{Y})$ positively. According to the interpretation table proposed by Sugiyono (2013), the correlation rate between $\mathrm{X}_{1}$ and $\mathrm{X}_{2}$ with $\mathrm{Y}$ lies in the coefficient interval between 0.20 and 0.399 , therefore on the low category. The coefficient of determination score of $\mathrm{X}_{1}$ variable with $\mathrm{X}_{2}\left(\mathrm{r}^{2} \mathrm{X}_{1}, \mathrm{X}_{2}, \mathrm{Y}\right)$ is 0.131 . It shows that learning motivation and family background influences the motivation to start a business for $13.10 \%$ for the students in architectural engineering study program, while the other $86.90 \%$ is determined by other factors. While for the architectural engineering education study program, the learning achievement and family background influences the motivation to run a business as well. It is in line with the result of simple regression analysis whereas the $t_{\text {count }}$ score is positive 0.185 , which means that learning achievement and family background influence the motivation to run a business. According to Sugiyono's interpretation table, the correlation between the variables lies in the coefficient interval between 0.00 and 0.199 , which is categorized as very low. The coefficient of determination score of $\mathrm{X}_{1}$ variable with $\mathrm{X}_{2}\left(\mathrm{r}^{2} \mathrm{X}_{1}, \mathrm{X}_{2}, \mathrm{Y}\right)$ is 0.034 . It shows that the learning motivation and family background influences the motivation to run a business for $3.42 \%$ while the other $96.58 \%$ is determined by other factors. With the results from the two study programs, the extrinsic factors in motivation to start a business is not having much influence. Presumably, the intrinsic factors such as passion, psychological state, creativity, skills, and experience could influence much stronger.

\section{DISCUSSION}

\section{A. Summary of the Results Architectural Engineering}

TABLE I. SUMMARY OF THE RESULTS ARCHITECTURAL ENGINEERING

\begin{tabular}{|c|c|c|c|c|c|}
\hline $\begin{array}{l}\text { Correlated } \\
\text { variables }\end{array}$ & $\mathrm{t}_{\text {count }}$ & Category & Decision & $\begin{array}{l}\text { Regression } \\
\text { equation }\end{array}$ & KD \\
\hline $\begin{array}{l}\text { Learning } \\
\text { achievement } \\
\text { and family } \\
\text { background }\end{array}$ & $\begin{array}{l}0.030 \\
(\mathrm{X} 1- \\
\mathrm{X} 2)\end{array}$ & Low & $\begin{array}{l}\text { Significa } \\
\text { nce }\end{array}$ & $\begin{array}{l}\hat{Y}=51.609 \\
-0.030 X_{1}\end{array}$ & $\begin{array}{l}0.09 \\
\%\end{array}$ \\
\hline $\begin{array}{l}\text { Learning } \\
\text { achievement } \\
\text { and } \\
\text { motivation to } \\
\text { run a business }\end{array}$ & $\begin{array}{l}0,017 \\
\left(\mathrm{X}_{1^{-}}\right. \\
\mathrm{Y})\end{array}$ & Very low & $\begin{array}{l}\text { Significa } \\
\text { nce }\end{array}$ & $\begin{array}{l}\hat{Y}=48.948 \\
+0.018 X_{1}\end{array}$ & $\begin{array}{l}0.02 \\
\%\end{array}$ \\
\hline $\begin{array}{l}\text { Family } \\
\text { background } \\
\text { and } \\
\text { motivation to } \\
\text { run a business }\end{array}$ & $\begin{array}{l}0,361 \\
\left(\mathrm{X}_{2^{-}}\right. \\
\mathrm{Y})\end{array}$ & Low & $\begin{array}{l}\text { Significa } \\
\text { nce }\end{array}$ & $\begin{array}{l}\hat{Y}=31.487 \\
+0,366 X_{2}\end{array}$ & $\begin{array}{l}13.0 \\
3 \%\end{array}$ \\
\hline $\begin{array}{l}\text { Learning } \\
\text { achievement } \\
\text { and family } \\
\text { background, } \\
\text { and } \\
\text { motivation to } \\
\text { run a business }\end{array}$ & $\begin{array}{l}0.362 \\
\left(\mathrm{X}_{1}\right. \\
\mathrm{X}_{2^{-}} \\
\mathrm{Y})\end{array}$ & Low & $\begin{array}{l}\text { Significa } \\
\text { nce }\end{array}$ & $\begin{array}{l}\hat{Y}=29.998 \\
+\quad 0.029+ \\
0.367 X_{1} X_{2}\end{array}$ & $\begin{array}{l}13.1 \\
0 \%\end{array}$ \\
\hline
\end{tabular}

DiAGRAM OF THE RESULTS

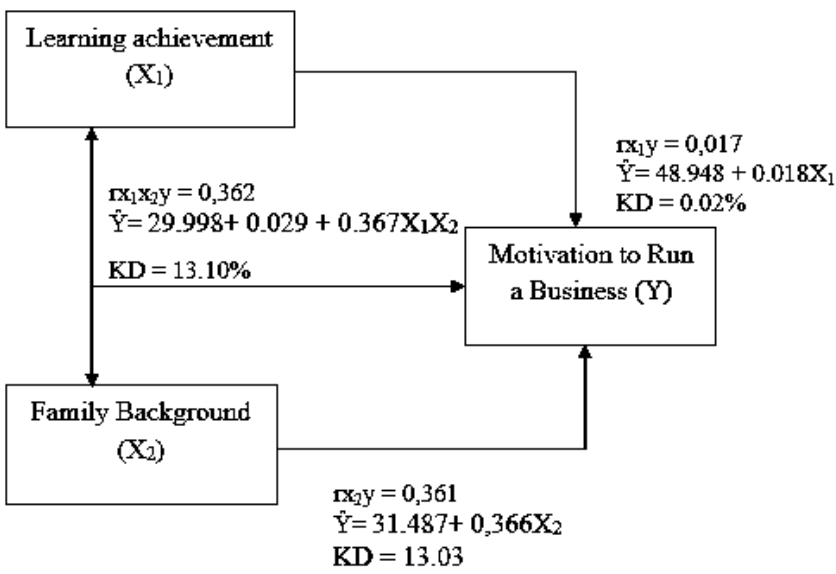

Summary of the Results Architectural Engineering Education

TABLE II. SUMMARY OF THE RESULTS ARCHITECTURAL ENGINEERING EDUCATION

\begin{tabular}{llllll}
\hline $\begin{array}{l}\text { Correlated } \\
\text { variables }\end{array}$ & $\mathrm{t}_{\text {count }}$ & Category & Decision & $\begin{array}{l}\text { Regression } \\
\text { equation }\end{array}$ & KD \\
\hline Learning & 0,243 & Low & Significa & $\hat{Y}=38.545$ & 5.90 \\
achievement & X1- & & nce & $+0.233 \mathrm{X} 1$ & $\%$ \\
& $\mathrm{X} 2)$ & & & &
\end{tabular}




\begin{tabular}{|c|c|c|c|c|c|}
\hline $\begin{array}{l}\text { Correlated } \\
\text { variables }\end{array}$ & $t_{\text {count }}$ & Category & Decision & $\begin{array}{l}\text { Regression } \\
\text { equation }\end{array}$ & $\mathrm{KD}$ \\
\hline $\begin{array}{l}\text { and family } \\
\text { background }\end{array}$ & & & & & \\
\hline $\begin{array}{l}\text { Learning } \\
\text { achievement } \\
\text { and } \\
\text { motivation to } \\
\text { run a business }\end{array}$ & $\begin{array}{l}0,155 \\
(\mathrm{X} 1- \\
\mathrm{Y})\end{array}$ & Very low & $\begin{array}{l}\text { Significa } \\
\text { nce }\end{array}$ & $\begin{array}{l}\hat{Y}=57.250 \\
-0.147 X 1\end{array}$ & $\begin{array}{l}2.40 \\
\%\end{array}$ \\
\hline $\begin{array}{l}\text { Family } \\
\text { background } \\
\text { and } \\
\text { motivation to } \\
\text { run a business }\end{array}$ & $\begin{array}{l}0.061 \\
(\mathrm{X} 2- \\
\mathrm{Y})\end{array}$ & Very low & $\begin{array}{l}\text { Significa } \\
\text { nce }\end{array}$ & $\begin{array}{l}\hat{Y}=46.922+ \\
0.061 X 2\end{array}$ & $\begin{array}{l}0.37 \\
\%\end{array}$ \\
\hline $\begin{array}{l}\text { Learning } \\
\text { achievement } \\
\text { and family } \\
\text { background, } \\
\text { and } \\
\text { motivation to }\end{array}$ & $\begin{array}{l}0,185 \\
(\mathrm{X} 1 \\
\mathrm{X} 2- \\
\mathrm{Y})\end{array}$ & Very low & $\begin{array}{l}\text { Significa } \\
\text { nce }\end{array}$ & $\begin{array}{l}\hat{Y}=53.230- \\
0,171+ \\
0.104 X 1 X 2\end{array}$ & $\begin{array}{l}3.42 \\
\%\end{array}$ \\
\hline
\end{tabular}

DiAGRAM OF THE RESULTS

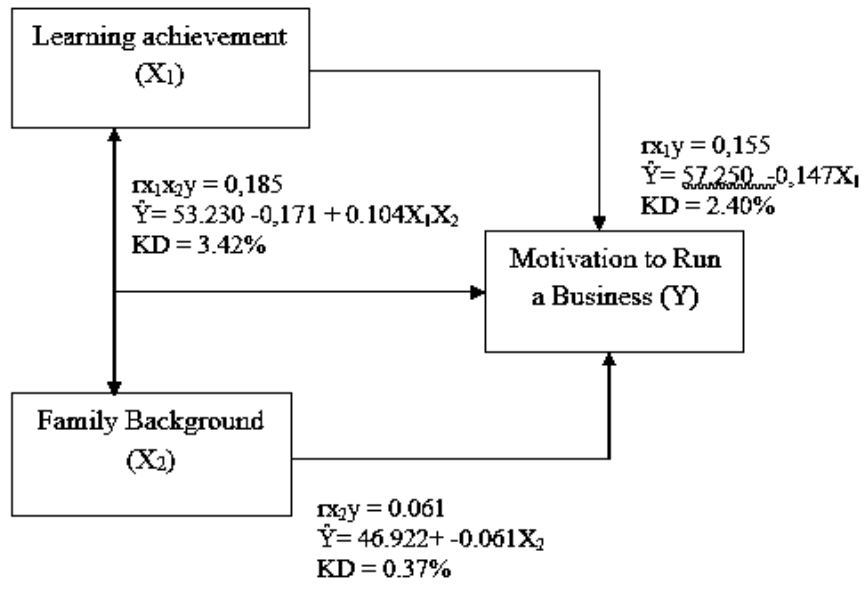

\section{CONCLUSION}

After the data analysis and the discussion, therefore several points can be concluded, i.e.:

- Learning achievement gives a few influences to the motivation to run a business in the architectural engineering study program. It gives very little influence as well in the architectural engineering education study program.

- In the architectural engineering study program, backgrounds influence the motivation to run a business in a low level, whereas in the architectural engineering education study program, the influence is in a very low level.

- Learning motivation and family background influence a little in the architectural engineering study program and they influence very little in the architectural engineering education study program. 